\title{
Masculinidades en Raiders of the Lost Ark (Spielberg 1981)
}

\author{
José Díaz-Cuesta
}

Universidad de La Rioja

jose.diaz-cuesta@unirioja.es

\section{Introducción}

La obra de Steven Spielberg está comenzando a gozar de reconocimiento académico en España. David Caldevilla Domínguez publica en este año 2005, fruto de su tesis doctoral, El sello Spielberg, localizando los estilemas del director apoyándose en la de momento trilogía de Indiana Jones. Precede a esta obra la versión divulgativa de otra tesis doctoral, realizada por Antonio Sánchez-Escalonilla (1994), publicada en 1995 y extendida en 2004.

Fuera de España cabe también destacar la compilación de Yosefa Loshitzky (1997) centrada en Schindler's List (Spielberg 1993), y la de Charles Silet (2002), que abarca diversas obras del director.

Pero ninguno de los autores mencionados cifra en la representación de masculinidades la cuestión de sus investigaciones, hueco que nos proponemos rellenar, en lo que atañe a Raiders of the Lost Ark (Spielberg 1981a), en este artículo.

\section{Una nota sobre el método}

Para ello seguimos un método analítico-sintético en el que consideramos los cuatro entornos o sites en los que las autoras Pat Kirkham y Janet Thumim (1993: 11) consideran la representación de masculinidades en películas cinematográficas: el cuerpo, la acción, el mundo externo y el mundo interno.

La masculinidad de un hombre o un personaje no deja de ser un rasgo caracterizador. Seymour Chatman (1986: 126) ve a los personajes constituidos por un conjunto de rasgos, sin incluir la masculinidad -o masculinidades- entre los mismos. Pero Kirkham y Thumim, en el capítulo introductorio de You Tarzan: Masculinites, Movies and Men, cuyos demás capítulos están escritos únicamente por hombres, sí atienden a las representaciones como ese conjunto de sites que hemos mencionado, en cada uno de los cuales es posible explorar diversos rasgos caracterizadores.

Esos cuatro entornos coinciden en gran manera con los ambientes explorados por Raewyn Connell en Masculinities (1995), estudio sociológico de masculinidades 
australianas cuya base se sustenta en entrevistas realizadas por la autora a hombres que reflexionan sobre sí mismos.

Dedicamos los próximos cuatro apartados a cada uno de esos entornos, si bien en ocasiones sus contenidos se solapen ligeramente, y no dudando en volver sobre alguna escena que merece ser considerada en más de un entorno ${ }^{1}$.

\section{El cuerpo en Raiders of the Lost Ark}

De acuerdo con Kirkham y Thumim, a la hora de analizar el cuerpo o cuerpos que dan vida a las masculinidades de un texto cinematográfico hay que fijarse no sólo en la manera en la que esos cuerpos se ofrecen a la mirada del espectador, sino también en la star persona de los actores que encarnan a esos personajes.

En el caso de Raiders of the Lost Ark no hay duda alguna sobre en quién debemos fijarnos: Harrison Ford es la estrella de la película. Tom Sellek había sido la primera opción, pero finalmente se optó por Ford. El primero habría aportado una apariencia aún más de tipo duro, el segundo tenía el problema de haber colaborado en varias ocasiones con George Lucas, quien no deseaba que se le vinculara a un único actor.

A pesar de haber colaborado en dos ocasiones en papeles menores con Francis Ford Coppola, en The Conversation (1974) y Apocalypse Now (1979), el actor llegaba al papel de Indiana Jones con la impronta de haber representado en dos ocasiones a Han Solo en las dos entregas que Lucas había estrenado de su trilogía galáctica, Star Wars (1977) y The Empire Strikes Back (1980). La segunda había sido la película en la que los espectadores habían podido ver en la gran pantalla a Ford el año anterior del estreno de Raiders. El personaje de Solo aporta el estigma de aventurero que continúa en la aventura arqueológica dirigida por Spielberg. No obstante, sería con esta última película con la que el antaño carpintero alcanzaría el estrellato absoluto y la máxima consideración entre el público mainstream. Después llegarían otras interpretaciones que ahondan en el matiz aventurero, incluyendo el Rick Deckard de Blade Runner (Scott 1982) al año siguiente. En Ford se funde el atractivo físico con un toque de improvisación, de no estar actuando ("I don't know. I'm making this up as I go", dice su personaje en Raiders), que ha cautivado a audiencias de varias generaciones.

En parte, Spielberg va contra sus propias palabras, cuando se refería a la exclusión de actores muy conocidos en sus obras anteriores, según lo recoge John Baxter: "[i]t's very hard when you have an icon playing an ordinary person" (Baxter 1996: 125). Pero solo en parte, ya que cuando se produce la fusión entre actor y personaje es precisamente con Raiders of the Lost Ark y las dos películas que han

\footnotetext{
${ }^{1}$ Véase Díaz-Cuesta (2003) para comprobar una aplicación previa de este método también referida al texto fílmico Jaws (Spielberg 1975).
} 
continuado su estela hasta la fecha, Indiana Jones and the Temple of Doom (Spielberg 1984) e Indiana Jones and the Last Crusade (Spielberg 1989a).

Una referencia insoslayable del mito que se crea con este texto fílmico es el personaje de James Bond en las diferentes películas que ha protagonizado. Estamos de acuerdo con Andrew Rissik cuando afirma que:

Indiana Jones, I would argue, is James Bond relocated and filtered through our collective memory of the old movie serials. Pauline Kael once described the mood of the Bond series as "precariousness glorified," and that's exactly the right phrase for the vertiginous aestheticised suspense of Raiders Of The Lost Ark and Spielberg's previous action-knockout, Jaws. (Rissik 1984: 13)

Kirkham y Thumim prestan también importancia a la manera en la que se muestra en el texto fílmico la fisonomía de los hombres en sus caracterizaciones, especialmente en el caso de los protagonistas.

Al igual que sucede en la vida real, la primera impresión que nos causa un personaje puede resultar determinante para la forma en la que lo percibamos durante el resto de la película.

En Raiders se realiza una aproximación canónica, clásica, del cuerpo del Dr. Indiana Jones desde el mismo arranque del film. Se nos dan detalles del mismo como haría años más tarde Spielberg al introducir a Oskar Schindler en Schindler's List (1993)—, empezando por su silueta (F01).

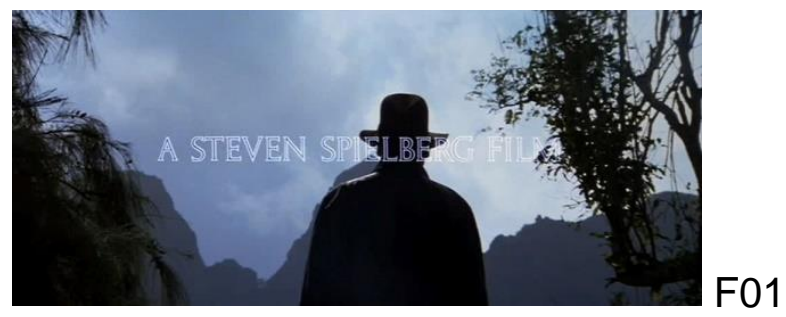

Pero antes de llegar ahí la cámara nos ha dejado ver el logotipo de los estudios Paramount (F02a), que se funden con una imagen de una montaña (F02a) frente a la que encontramos a nuestro héroe (F02b). 

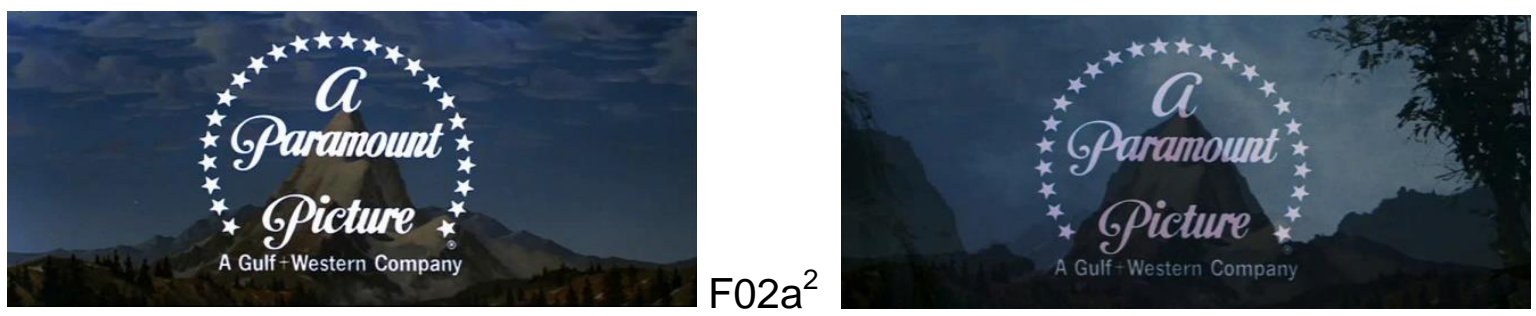

$\mathrm{F} 02 \mathrm{~b}$

Su figura, en plano medio de espaldas y a contraluz, le emparenta con el western, ya que su sombrero, tan típico de los cowboys, le caracteriza singularmente. El nombre del director se superpone, en la primera imagen que habíamos seleccionado (F01), sobre esa cabeza fundida con la montaña, montaña que entronca con la primera escultura fallida que Roy Neary (Richard Dreyfuss) esculpe en su propia casa en Close Encounters of the Third Kind (Spielberg 1977). La montaña inicial de Raiders, como la esculpida por Neary, goza de connotaciones fálicas que Jones incorpora al formar una unidad visual con la misma.

Lo siguiente que divisamos del protagonista son sus manos (F03), vinculadas al mapa antiguo que le ha pasado uno de sus ayudantes: el propósito indagador e investigador de ese cuerpo queda definido por su interés en el mapa.
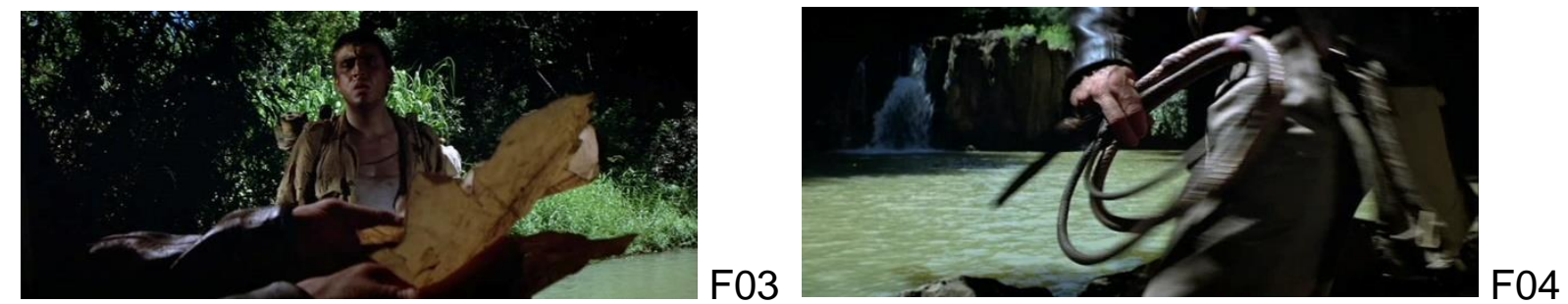

Ese interés es compartido por otro de sus ayudantes, que intenta arrebatarle el documento, a lo que Jones responde haciendo uso de su látigo (F04). El látigo alcanza su máxima extensión cuando es utilizado con acierto y sirve con eficacia a su propietario. Las connotaciones fálicas aún son más evidentes que con la montaña inicial. De hecho el látigo se había intuido, aunque no visto con claridad, en esa toma inicial (F05): ya se veía que algo colgaba de ese cuerpo.

\footnotetext{
${ }^{2}$ La letra minúscula al final de la notación de imágenes con la misma numeración indica que esos fotogramas pertenecen a la misma toma.
} 

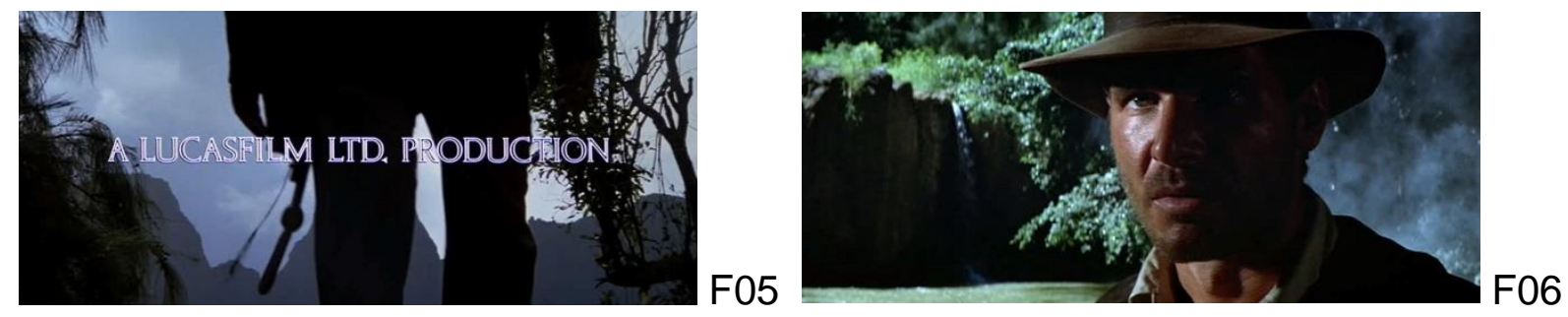

Por fin, tras el misterio creado alrededor del cuerpo del Dr. Jones, se nos desvela su rostro, aunque no se nos deja verlo por completo (F06), como queriendo mantener parte de ese misterio. Ahí apenas si se divisa la cicatriz de su barbilla, uno de los rasgos físicos distintivos del arqueólogo. La herida está disimulada por la barba de pocos días que suele lucir en sus misiones, en una imagen de tipo duro prestada de nuevo del western que tuvo bastante predicamento en los años ochenta del pasado siglo y que desde entonces sigue teniendo buena aceptación entre los hombres occidentales. Durante los casi cuatro minutos que han transcurrido de película aún no hemos oído ninguna voz que se corresponda con esa figura, ni siquiera ahora cuando su integridad física se ha visto amenazada.

El resto del atuendo de Jones lo conforman su bolsa y su cazadora. La primera era la usada por el ejército británico durante la Segunda Guerra Mundial para transportar máscaras de gas, y a Jones le resulta de lo más útil para conservar en ella algunos de sus hallazgos, como el ídolo que está a punto de descubrir en esta primera secuencia. La segunda está inspirada en las cazadoras de cuero de la época, también de uso militar, aunque no se corresponde con ningún modelo concreto. Un dato relevante en relación con la misma procede del hecho de que esté envejecida, en alusión a la edad de Indiana Jones, que ya no es un jovencito, y a su experiencia: al "mileage" al que hace referencia en su escena de amor con Marion (Karen Allen) en el barco. Tanto la bolsa como la cazadora tienen claras connotaciones militares, recordándonos que ese cuerpo, además de encontrarse buscando tesoros, se halla inmerso en un mundo que en 1936 se estaba preparando para la Segunda Guerra Mundial, que comenzaría tres años después.

Por otra parte, cazadora y sombrero difieren poco de lo que había llevado puesto Charlton Heston como Harry Steele (F07) en Secret of the Incas (Hopper 1954), película a la que Raiders le debe algo más que la apariencia de su héroe. 


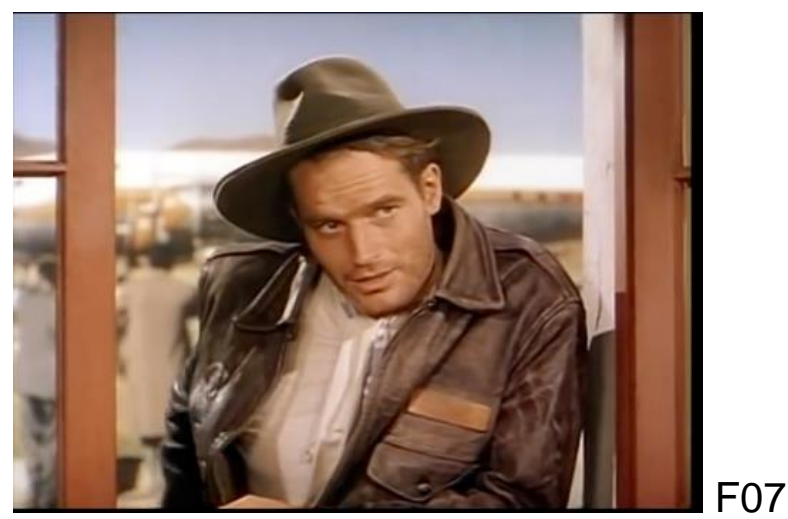

Pero el Dr. Jones no presenta únicamente ese aspecto a lo largo de la película. Hay otra indumentaria con la que también se le identifica, aunque resulte menos carismática que su atuendo de campo, como dicen los arqueólogos. Me refiero a su apariencia cuando se encuentra dando clases en la universidad a la que pertenece: gafas redondas algo sobredimensionadas, traje con chaleco y corbata (F08).

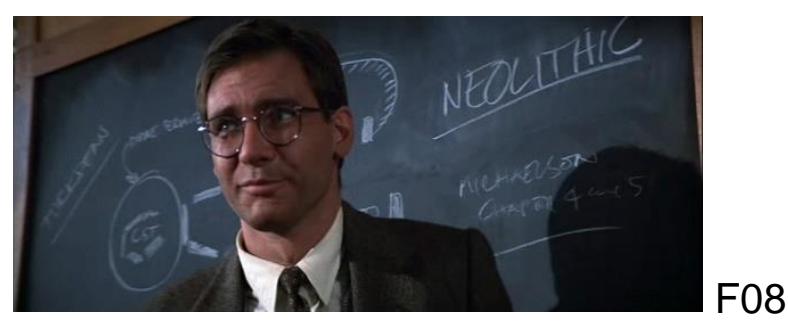

Aunque Jones no sea un superhéroe, sí goza casi de una doble personalidad, como advertíamos en 1998:

There are two main features which Indiana shares with him [Superman], which are common to most superheroes: the need to dress up in order to work, and the usage of a double identity. In the case of the archeologist none of those features is so important as they are for superheroes, although Indy seems to need both of them to keep on being Indy. (Díaz-Cuesta 1998: 220)

El lenguaje corporal del Dr. Jones se vuelve mucho más torpe cuando está dando clase. Pero a diferencia de los superhéroes, él no oculta su personalidad: la clase que está impartiendo versa sobre la aventura que acaba de correr, aunando la 
teoría con la práctica, como los mejores profesores. El plano que ha dibujado en la pizarra y las diversas tallas que pueblan la mesa del profesor (F09) le delatan en su condición de buscador de tesoros.

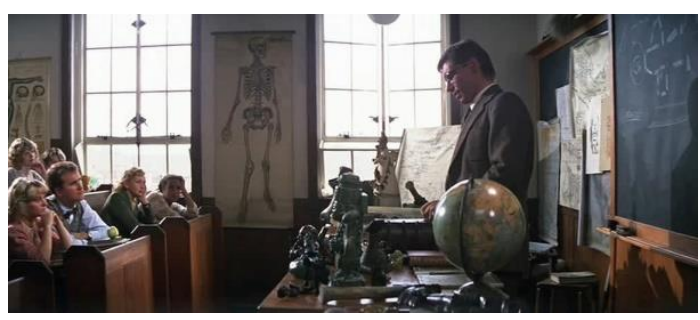

\section{Fo9}

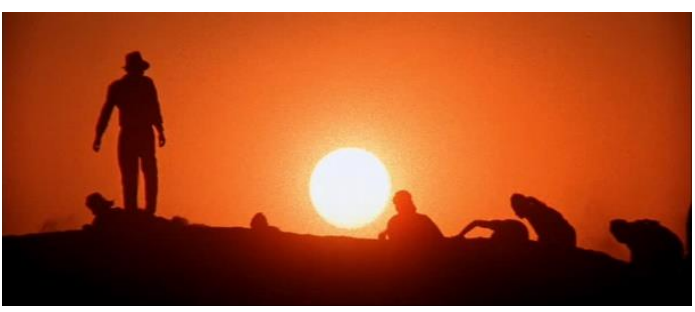

F10

La silueta del arqueólogo es reconocible de nuevo cuando su equipo está excavando para acceder al Pozo de las Ánimas (F10). De hecho ahí observamos uno de sus cambios de indumentaria: tras vestirse camuflado como un egipcio (F11), se transforma a contraluz (F12) en el Indy que cualquier espectador es capaz de reconocer a esas alturas de la película.
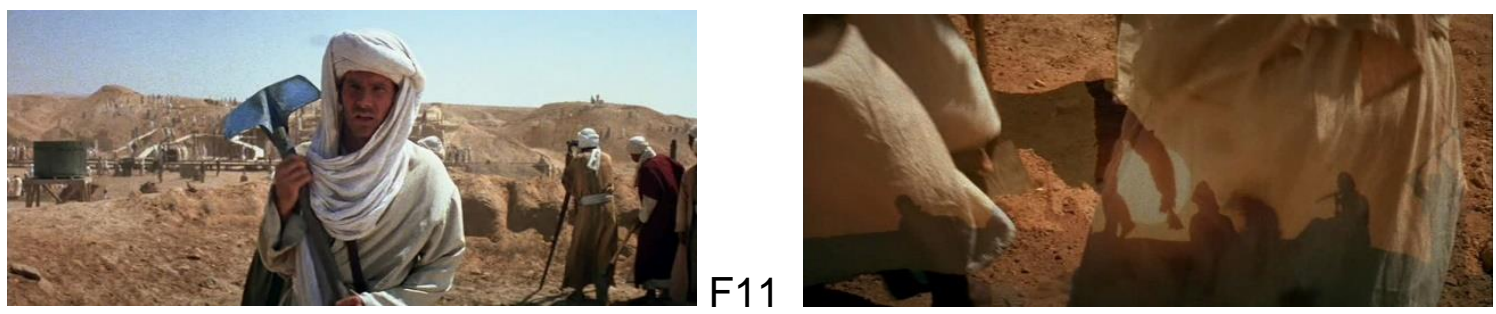

F12

Resulta destacable la capacidad camaleónica del arqueólogo, que no duda en vestirse como un soldado nazi (F13) para poder seguir los pasos de Marion y del Arca de la Alianza.

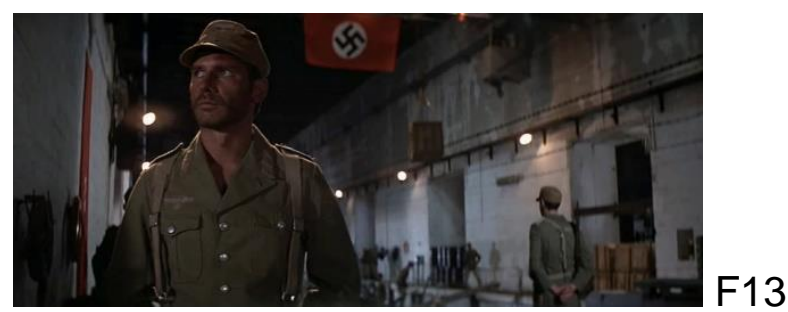


Se refuerza la idea primigenia de Spielberg de que Jones podría haber sido cualquiera de sus espectadores, aumentándose de esta manera la capacidad de identificación con el protagonista.

\section{La acción en Raiders of the Lost Ark}

En una película de acción y aventuras como la que George Lucas y Steven Spielberg concibieron en su mítica conversación en la playa (Spielberg 1981b: 1100; Baxter 1996: 2) la acción está presente desde el arranque de la primera secuencia, en la que Indiana Jones hace uso de su látigo por primera vez en pantalla. Su habilidad con el mismo le sitúa más allá del profesor universitario y del arqueólogo, más cerca de nuevo de los superhéroes, que suelen tener un don especial o un arma distintiva. Pero a diferencia de estos, a Jones se le puede encontrar en situaciones poco dignas, huyendo más que afrontando peligros, como cuando escapa de las cerbatanas de los hovitos en la resolución de esa secuencia inicial (F14).
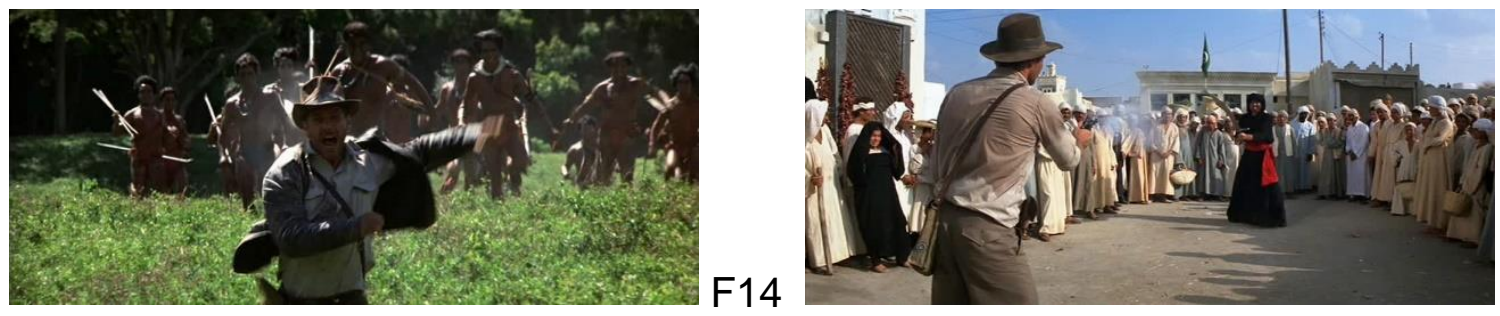

F15

A pesar de su solvencia con el látigo, o precisamente por ello, una de las escenas que más se recuerda de esta película es aquélla en la que el arqueólogo responde con un disparo de pistola -en lugar de usar el látigo o las manos - al desafío que le presenta un guerrero en El Cairo, armado con una enorme espada (F15).

Aunque el recurso al arma de fuego se debió a una improvisación de Ford motivada por el estado físico del actor, mermado por alguna comida que le había sentado mal y que le hacía acudir al baño cada pocos minutos, como se ha citado en numerosas ocasiones (por ejemplo en [Baxter 1996: 212]), su incorporación en el repertorio de acciones del arqueólogo no hace sino ahondar en su preferencia por las soluciones fáciles antes que las heroicas, sobre todo cuando se trata de salvar la vida. 
El látigo vuelve a ser lo primero que se oye y que apenas si se ve cuando Jones acude al rescate de Marion en la taberna que esta última regenta. Aunque el arqueólogo hace notar su presencia mediante el arma que le caracteriza, inmediatamente hace uso de una pistola: con la primera se presenta, con la segunda intenta ser más efectivo. Pero no habría salido victorioso del enfrentamiento con el equipo nazi sin la colaboración determinante de Marion: en parte de esta escena, y sobre todo en la que la precede, en la que la chica ha estado compitiendo bebiendo contra un oponente masculino de gran envergadura, se produce una suerte de inversión de valores o de papeles (suele citarse como reversal of values en inglés), ya que es la chica quien aporta la actitud más tradicionalmente masculina, asociada con la bebida y con la violencia: en un momento determinado de la pelea con los nazis, ella incluso se detiene para beber el licor que se está desperdiciando de un barril tiroteado (F16): ese momento supone la inflexión de la escena en cuanto a la actitud de Marion, ya que desde el comienzo del tiroteo se había mostrado asustada por los disparos y los ruidos que generan, y a partir del trago de alcohol realiza acciones violentas que culminan con su uso de un arma de fuego que pone el punto final al enfrentamiento.
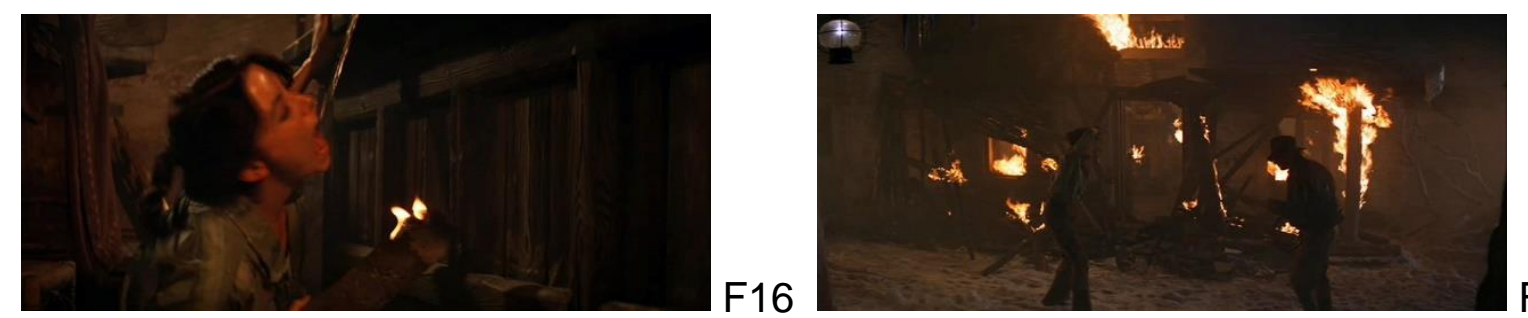

$\mathrm{F} 17$

Ella agradece la intervención del arqueólogo diciéndole de forma irónica "Well Jones, at least you haven't forgotten how to show a lady a good time" (F17). El comentario se realiza con un fondo de confusión y de fuego en el que de nuevo reconocemos al aventurero por su silueta.

El fuego juega un papel fundamental en esta escena, ya que gracias al mismo el torturador nazi se quema la mano con el medallón que se necesita para ser utilizado en la cámara de los mapas. Resulta paradójico que sea él precisamente quien se abrase la mano de esa manera, tras haber amenazado a Marion con quemarle alguna parte de su cuerpo. La quemadura, como las cicatrices, se constituye en resto arqueológico que inscribe sus datos en el cuerpo de su portador. En este caso, en uno de los oponentes del héroe: el dolor y la sabiduría pueden residir en cualquier lugar, siempre y cuando estemos dispuestos a aprender de ellos.

La escena que gira, literalmente, en torno a un avión que se encuentra en tierra con las hélices en movimiento en Egipto se cifra como la de mayor 
enfrentamiento físico del protagonista. La forma de actuar de Jones define aún más su personaje. En primera instancia intenta abordar al piloto de la aeronave sin que éste se aperciba, por la espalda (F18).
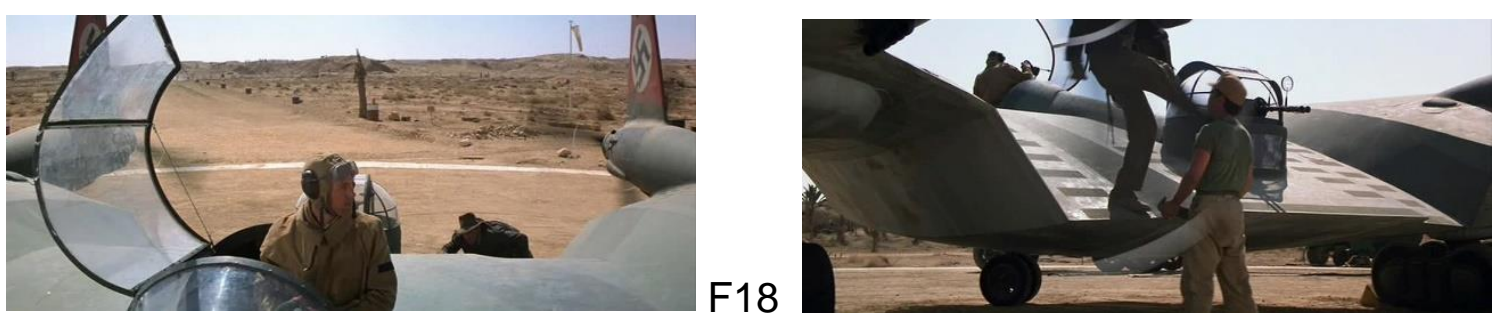

F19

Al ser sorprendido por otro soldado nazi que porta una amenazadora llave grifa, el arqueólogo reacciona dándole una patada en la cara (F19): ninguna de las dos acciones le caracteriza como alguien que juegue limpio, sino como alguien que busca la supervivencia en la lucha antes que cualquier otra cosa. En su defensa podemos alegar que su contrincante porta un arma, mientras que Jones sólo hace uso de sus puños.

La escena es observada por otro soldado que encarna al hombre más fornido del film (F20a): su respuesta a la lucha de la que es testigo no consiste en apresurarse a socorrer a su compañero, sino en quitarse la camisa para lucir su anatomía y poder disponerse a participar en una pelea sin que nada le estorbe. La posición que adopta la cámara le agiganta aún más (F20b): por su físico nos recuerda en parte a Quint en Jaws (Spielberg 1975), y por la planificación al camión/ero de Duel (Spielberg 1972).
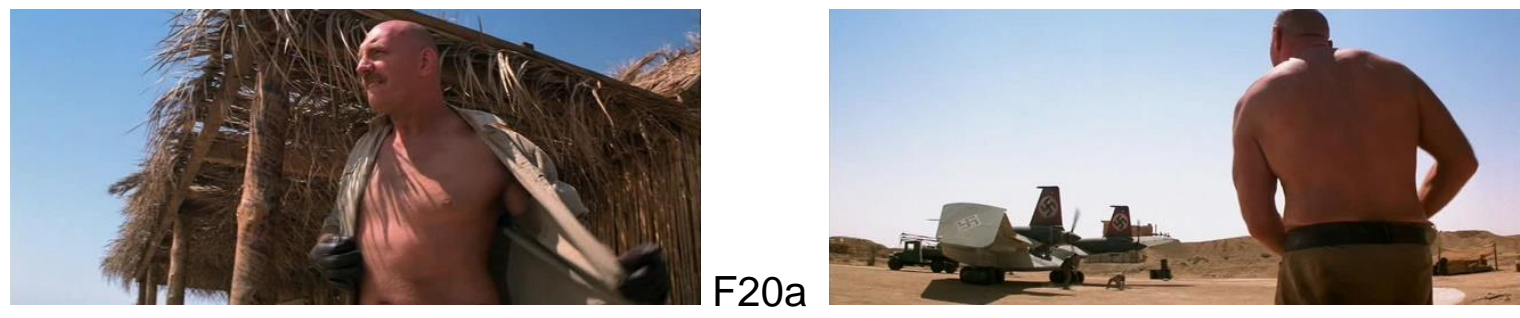

F20b

Incluso cuando el soldado reta a Jones, con este último en una posición elevada (F21), el nazi sigue pareciendo una mole monstruosa. Cabe subrayar que el soldado se ha desprendido también de los guantes: busca el contacto físico, el cuerpo contra cuerpo, la acción en estado puro, y con ello el disfrute del espectador que esté ávido de este tipo de espectáculo. Jones reacciona de manera cómica, 
como dando a entender que ya está bien de tanta pelea, y que se le va a hacer muy cuesta arriba esta lucha en concreto (F22).
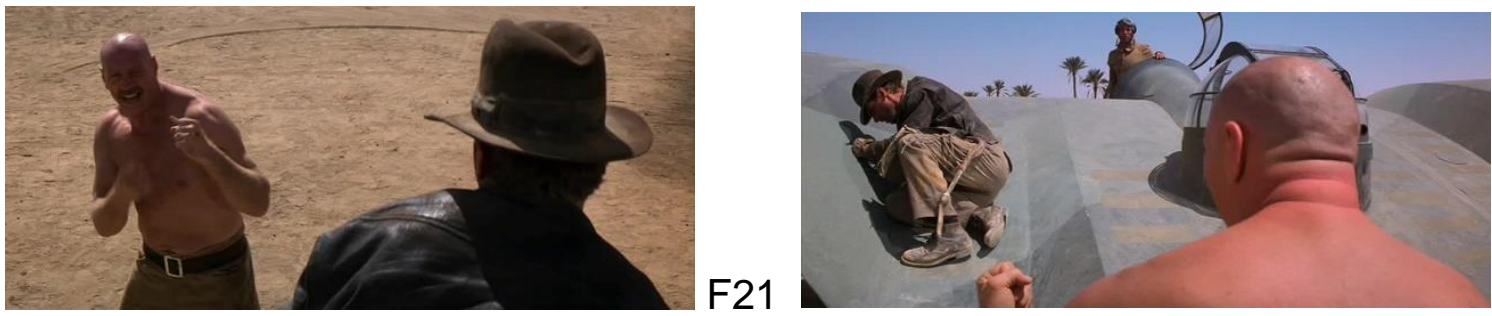

F22

Podríamos esperar que Jones recurriese de nuevo a la pistola para eludir el enfrentamiento, pero no hace el más mínimo intento de acceder a ella, bien porque no la porta o porque no quiere hacer demasiado ruido y ser sorprendido por todo el destacamento. Cuando parece que ha aceptado la pelea y se dispone a luchar en actitud pugilística, el arqueólogo recurre una vez más al engaño, intentado compensar su inferioridad física con una mayor agudeza mental. Su oponente, sin embargo, no se inmuta ante el ataque, y tumba fácilmente a Jones, que cae al suelo de manera bastante cómica, como si fuera un muñeco (F23).

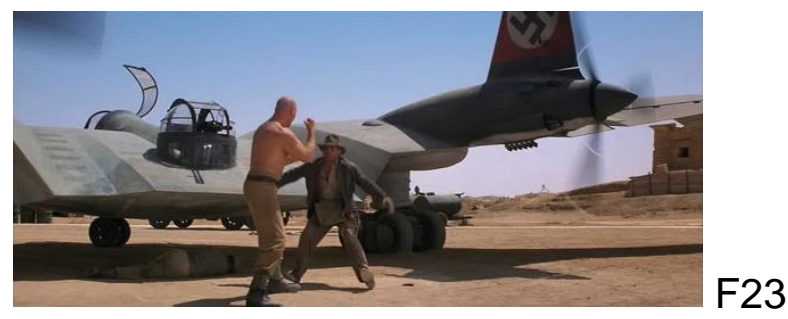

La comicidad aumenta cuando, tras aceptar continuar peleando y levantarse de la mano de su contrincante, le muerde a este último en el brazo (F24, F25).
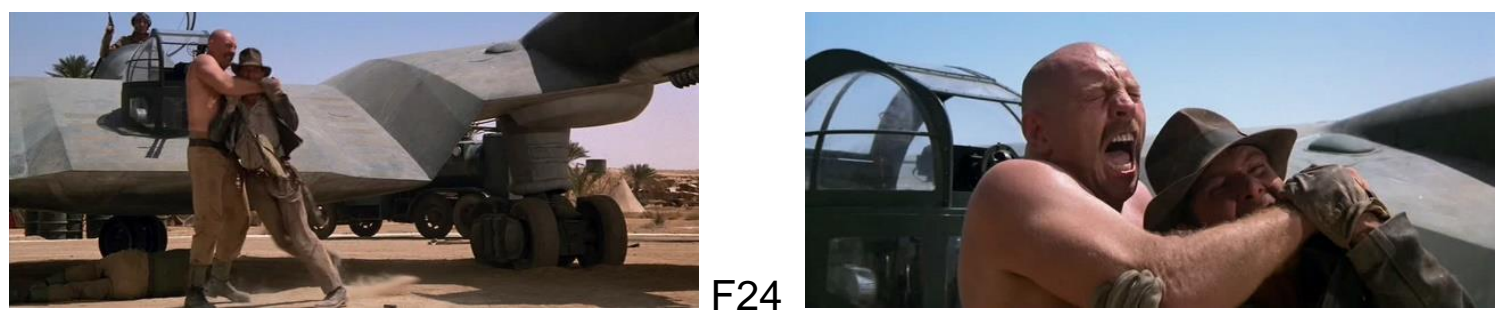
La escena continúa con el aderezo de la pistola del piloto, que intenta disparar a Jones, pero sin alcanzarle, primero por la pericia del explorador, y luego por la interposición de su musculoso contrincante (F26). El juego sucio de Jones aún no ha terminado, ya que opta por arrojarle arena a los ojos. Se insiste de esta manera en la caracterización de su personaje como alguien lleno de tretas y subterfugios, conocedor de sus limitaciones físicas.

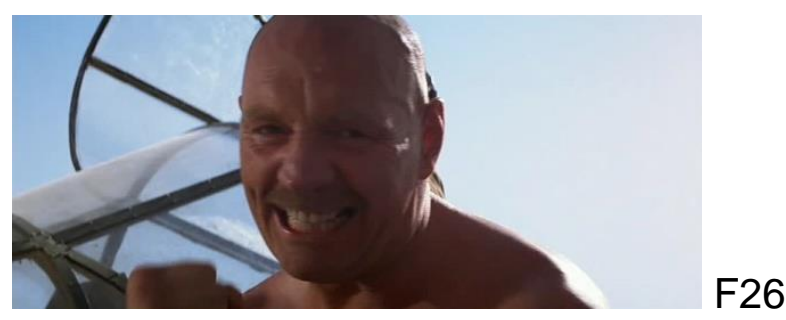

La intervención de Marion, poniendo fuera de juego al piloto, se realiza desde el punto de vista de la cámara en plano semi-subjetivo, donde no esperábamos que hubiera nadie más allá del emplazamiento del espectador, con el que la chica comparte el disfrute de la escena (F27): la actitud de la joven no se corresponde con la de alguien cuya vida está en peligro, sino con la de quien está participando en un juego. De hecho, cuando a continuación son sorprendidos por un grupo de soldados a bordo de un camión, Marion les dispara usando la ametralladora del avión como si se tratara de una atracción de feria (F28).

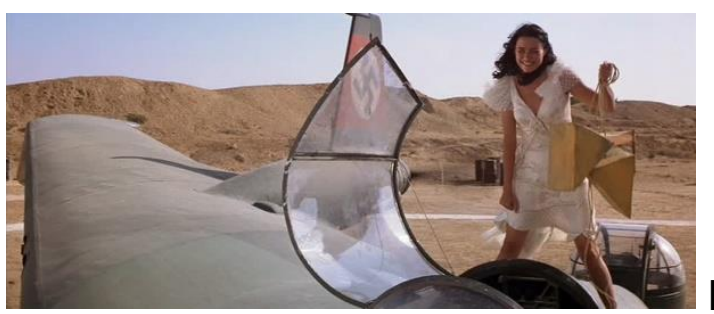

F27

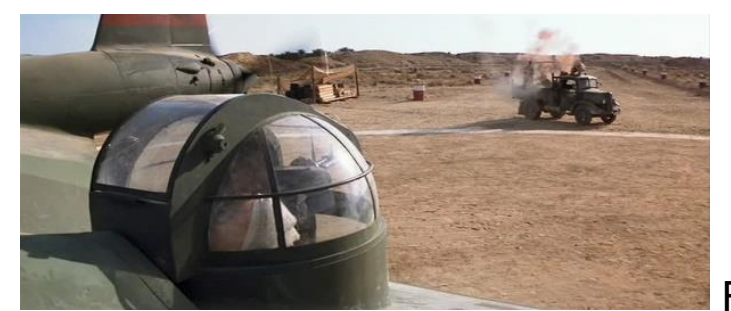

Poco después, un nuevo elemento aparece en escena: se trata de un camión cisterna del que empieza a salir combustible (F29): nos encontramos otra vez con una referencia al camión de Duel. Pero antes explosionan unos bidones (F30), fruto de algunos disparos fallidos de Marion. 

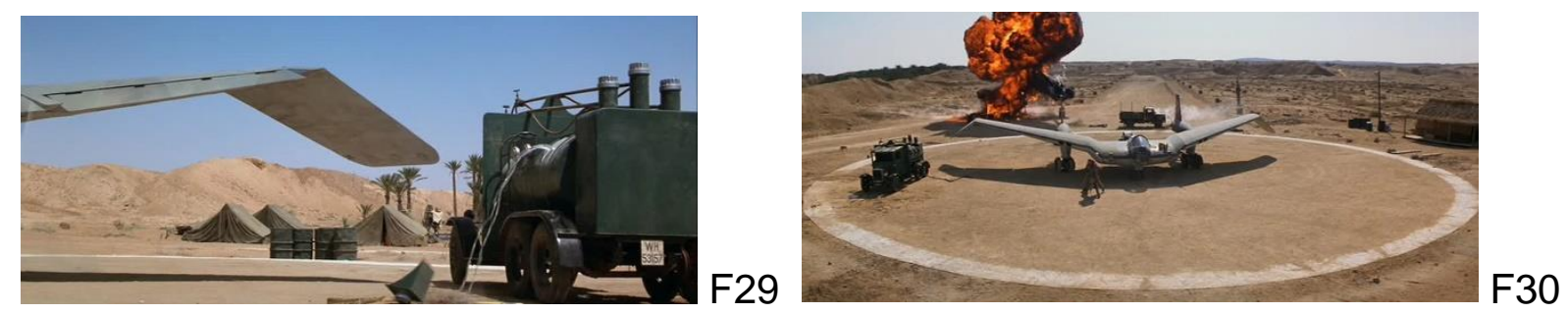

La detonación alerta a todo el campamento, incluidos sus máximos responsables. La lucha entre Jones y el soldado descamisado continúa, alcanzando el momento de inflexión en el que el nazi recibe sucesivos puñetazos en la cara que le hacen sangrar por varias partes de la misma (F31): a pesar de que Jones parece haber recibido los golpes más contundentes, quien refleja un mayor sufrimiento es su oponente, en un anticipo del desenlace, que no se llega a ver, y que tenemos que deducir por el montaje: su cuerpo ha tenido que ser fragmentado por la hélice del avión, y su sangre tiñe de rojo la bandera nazi de la aeronave (F32).

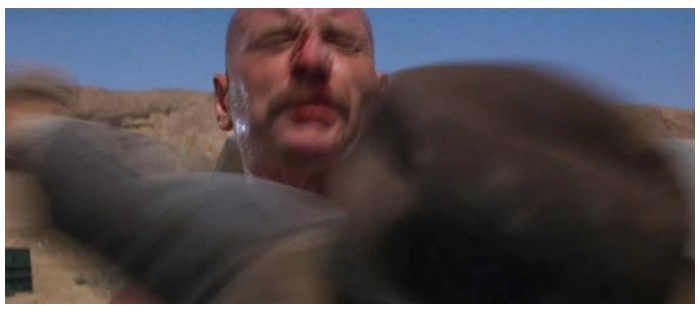

F31

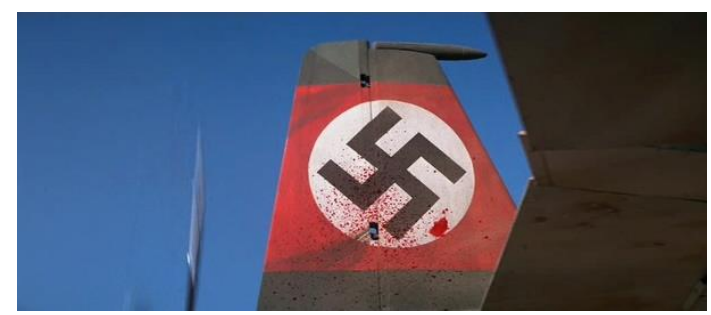

F32

Como suele ser habitual en Spielberg, la violencia más extrema es sustraída de la mirada del espectador, que tiene que imaginársela en su mente. En este caso la sangre llega a salpicar de manera abrumadora la carlinga en la que se halla Marion con los ojos cerrados (F33), compartiendo no sólo lo que no ve el espectador, sino lo que ha renunciado a ver el propio Indiana Jones: lo real en su estado más crudo e insoportable.

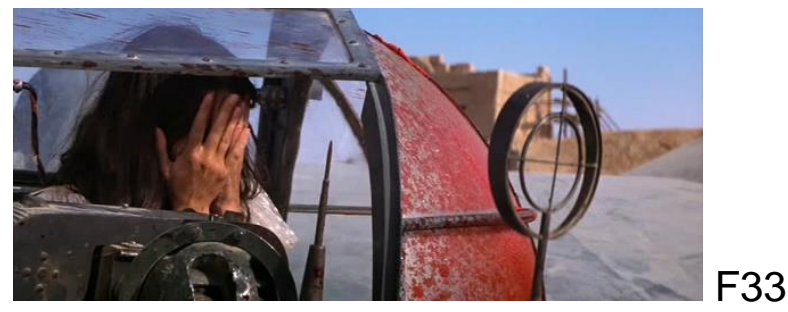

La escena concluye con la pareja huyendo del círculo que rodea al avión y al camión cuando explota este último (F34), inmediatamente antes de que suceda lo 
mismo con la aeronave: cuando logran reunirse las llamas subrayan la intensidad de su pasión.

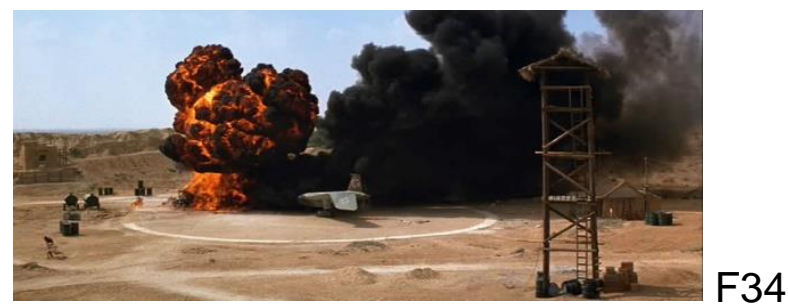

Otra escena cargada de acción sucede poco después, cuando Jones persigue montado a caballo el Arca, cargada en un camión y protegida desde otro vehículo dotado con una ametralladora. Cuando el arqueólogo logra el control del camión, Spielberg se homenajea una vez más a sí mismo, mostrándonos un plano del retrovisor del coche en el que viaja Belloq (Paul Freeman) (F35), como tantos similares que pueblan el universo de Duel. Pero en esta ocasión el camión está siendo conducido por el protagonista, y no por un personaje masculino misterioso cuya identidad desconocemos: a pesar de las deficiencias de Jones en cuanto a su físico, sí es capaz de conducir el camión que porta el Arca.
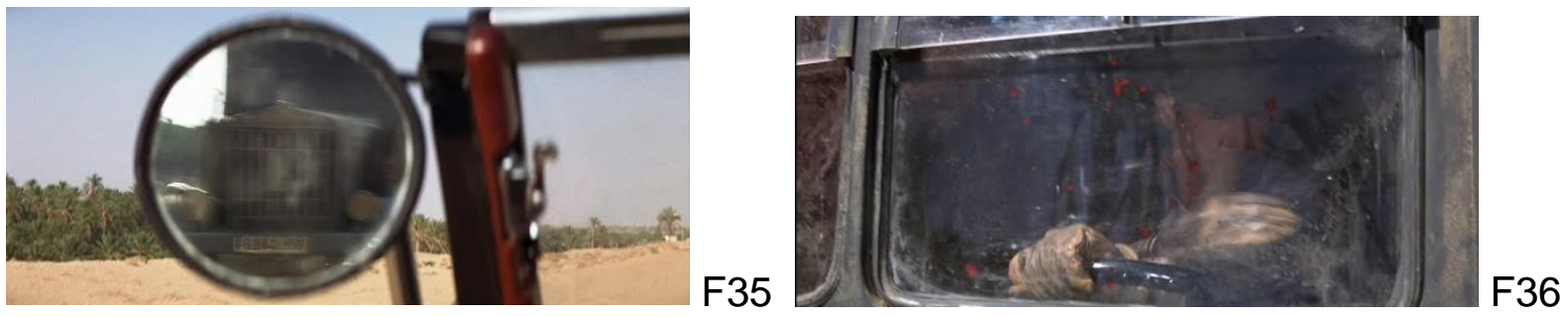

Mientras conduce, a Jones le alcanza un disparo procedente de uno de los soldados que transportaba el propio camión (F36): la sangre salpica el parabrisas del vehículo. El cuerpo del explorador es una vez más puesto a prueba frente al dolor y al sufrimiento.

Aprovechándose de la debilidad de Jones, el soldado le expulsa fuera de la cabina, dando lugar a uno de los momentos más exigentes para el especialista que dobló a Ford (F37), agarrado a los bajos del camión mientras éste avanza a toda velocidad. 

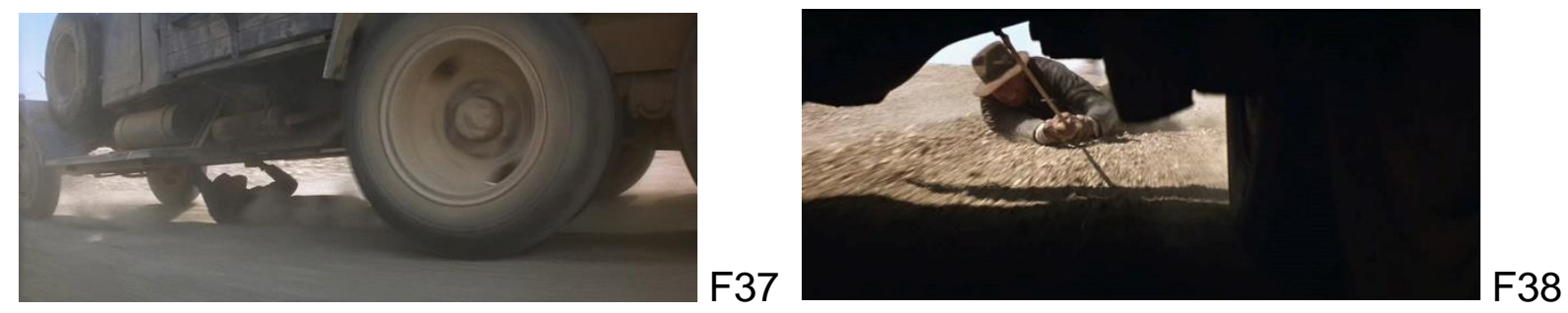

Se nos muestra así un plano que nos recuerda a Quint entrando en la boca del tiburón en Jaws (F38): en aquella ocasión entre el marino y las mandíbulas del escualo mediaba una ristra de boyas a modo de cordón umbilical en una suerte de parto hacia atrás, aquí el arqueólogo hace uso de su látigo para no perder el contacto con el camión, que hace las veces de mothership, al ser el vehículo que transporta el Arca.

Libre de sus enemigos, Jones puede ocuparse de su dolor por el tiro en el brazo (F39), que no le ha impedido conducir dando volantazos ni librarse del soldado, incapaz de emular al explorador cuando es a su vez expulsado de la cabina: el nazi no disponía de un látigo con el que engancharse al vehículo.

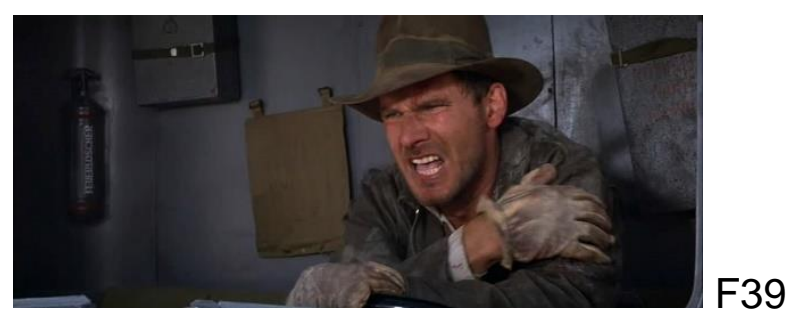

\section{El mundo externo en Raiders of the Lost Ark}

De entre las instituciones con las que se relaciona el protagonista de Raiders of the Lost Ark hay dos que destacan sobre las demás -la universidad y el ejército- y una tercera que se sitúa por encima de ellas —el gobierno de los Estados Unidos de América (y, en menor medida, el de Alemania). Por otra parte, el mundo externo de Indiana Jones también abarca sus relaciones con el universo femenino, centralizado en la figura de Marion. También cabría añadir aquí la religión, pero hemos preferido considerarla en el mundo interno porque creemos que constituye uno de los impulsos más íntimos del héroe en sus búsquedas. Procedemos a analizar todos estos mundos por separado, con ciertas conexiones entre algunos de ellos, como vemos a continuación.

La universidad se erige como justificación para las aventuras del arqueólogo. No debemos olvidar el título de la película, Raiders of the Lost Ark: aunque en 
España se tradujo como En busca del arca perdida, el término raiders alude a la condición de saqueadores o ladrones de quienes buscan tesoros arqueológicos.

Tras la trepidante secuencia inicial nos encontramos con el escenario mucho menos amenazador de un campus universitario en Nueva Inglaterra, que es introducido con un plano de situación de un edificio con una torre (F40).

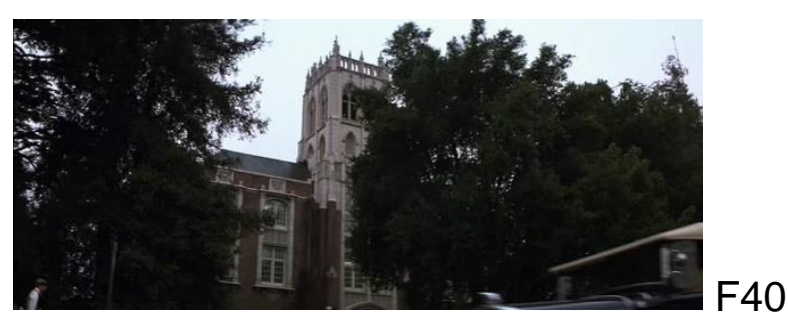

La presentación de Jones en el aula se realiza recurriendo a un plano de detalle de la pizarra, en la que el arqueólogo escribe la palabra "NEOLITHIC" dudando sobre su ortografía, lo que genera un pequeño momento cómico que es recibido por risas tanto por los alumnos de la clase como por cualquier espectador: se refuerza de esta manera el mayor valor de Jones como hombre de acción, de campo, que como intelectual. Por otro lado, cabe cuestionar la propia institución que lo alberga, capaz de aceptar a alguien con esas lagunas ortográficas (aunque finalmente escribe la palabra de la manera correcta). A pesar de ello, como hemos mencionado en el entorno del cuerpo, el Dr Jones aúna docencia e investigación, algo que no pueden decir todos los profesores universitarios.

Pero la razón por la que esta escena se recuerda fácilmente con posterioridad a su visionado no tiene que ver con lo académico ni lo aventurero, sino con la atracción física que Jones ejerce sobre sus alumnas. Así, la cámara recorre en travelín el aula, mostrando el embelesamiento de las estudiantes (F41), que alcanza su máxima expresión cuando, tras haber entrado Brody, se muestra un primer plano de una de las jóvenes, la cual lleva escrito en sus párpados las palabras "LOVE" y "YOU" (F42), lo que hace que Jones se fije en ella y titubee en su explicación, reaccionando de manera tímida y de nuevo cómica. Se subraya así la doble personalidad del Dr. Indiana Jones, aventurero y decidido en las labores de campo, dubitativo y tímido en el entorno estrictamente universitario. 

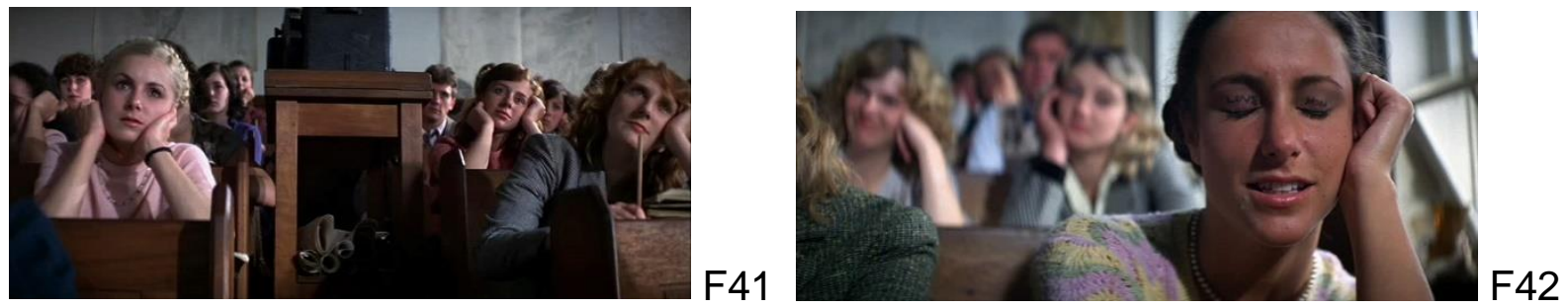

El aspecto académico de Jones sigue presente en su casa, en la que predominan los libros en dos grupos de estanterías empotradas en la pared, presididas por una variedad de tallas que reciben una iluminación especial (F43): el trabajo parece dominar la estancia principal de la casa, en la que también se encuentran los elementos de vestuario que caracterizan más a Indy que al Dr. Jones, elementos que permanecían ocultos en un armario y que vemos cuando se dispone a hacer la maleta (F44).
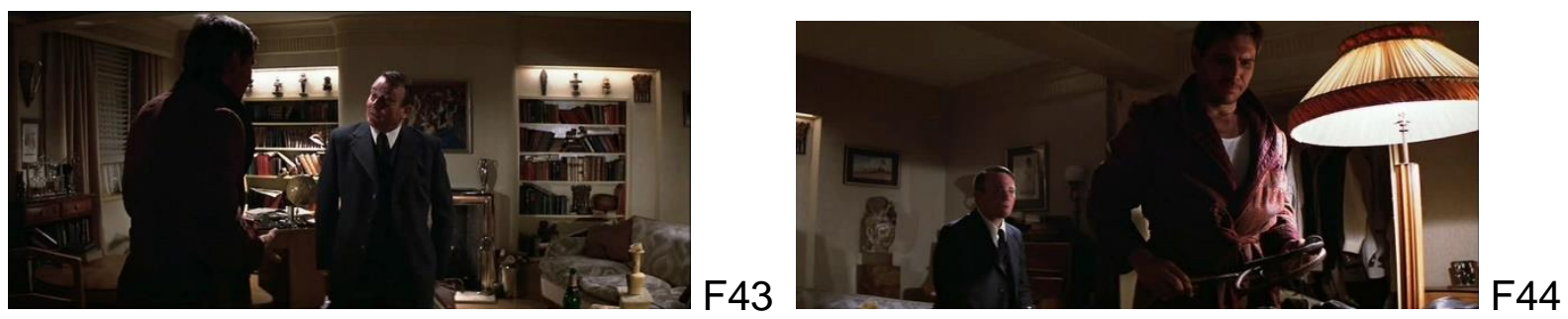

El ejército constituye otra institución con la que el Dr. Indiana Jones aparece relacionado a lo largo del film. Ya hemos mencionado la apariencia aventurera del arqueólogo, tomando prestados elementos de caracterización propios de la milicia, incluso vistiéndose como un soldado nazi, si bien lo hace con el objetivo de pasar desapercibido en su búsqueda de Marion y del tesoro.

Los soldados que recorren la película son principalmente nazis, y nos conducen al origen de sus órdenes, que no es otro que el führer Adolf Hitler, verdadero impulsor de la búsqueda que va a realizar Jones del Arca de la Alianza. En general, los soldados son fácilmente manejados por quienes tienen algún poder sobre ellos, aunque esos líderes no sean militares, como es el caso del Dr. René Belloq, como se puede observar en su control de los hovitos en la conclusión de la secuencia inicial, o en las diversas ocasiones en las que les dice a los soldados lo que tienen que hacer.

El ejército estadounidense está localizado en la Army Intelligence que visita a Jones en la universidad. Sus representantes contribuyen a la creación del mito de Indiana Jones planteando expectación a su alrededor. Comienzan diciéndole " $\mathrm{Dr}$ 
Jones, we've heard a great deal about you", para a continuación mencionar todos sus títulos: "Professor of Archaeology, expert on the occult and er -how does one say it?- obtainer of rare antiquities". En realidad están cuestionando la manera en la que Jones obtiene reliquias arqueológicas, aunque sus conocimientos y experiencia hacen que finalmente decidan contratarle. Los dos representantes conforman una pareja peculiar: uno de ellos parece conocerlo casi todo y va directamente al grano, el otro, que lleva una pajarita al cuello, es mucho más precavido y se expresa con circunloquios (F45). Su interés inicial no se centra en el Arca, sino en lo que han descifrado de unos mensajes nazis. Jones y Brody les guían sobre la pista del Arca. El último advierte de la invencibilidad de un ejército que tenga el Arca.
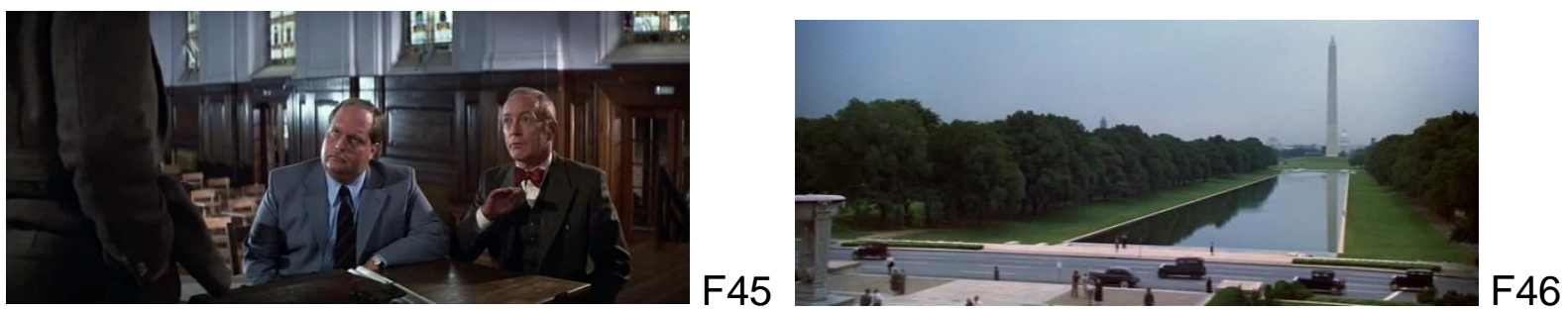

Al gobierno estadounidense le es otorgada la última palabra, empero, en lo que concierne al Arca. El cierre del film arranca tras el episodio en el que se abre el Arca, y es introducido por un plano de situación en el que se muestra el obelisco del Monumento a Washington (F46): la referencia al gobierno y a sus presidentes se hace patente.

La pareja de representantes de la Army Intelligence lleva la voz cantante en la nueva reunión que están manteniendo con Jones y Brody. Les dicen "You've done your country a great service". Todos coinciden en que la compensación económica que ha otorgado el gobierno ha sido satisfactoria. Pero Jones y Brody muestran un completo desacuerdo sobre lo que se va a hacer con el Arca. Brody exige que sea investigada, a lo que el representante responde que ya está siendo así, y que quienes lo están haciendo son "top men". Todo esto lo expresa sin quitarse la pipa de la boca (F47), y con un guardaespaldas al fondo, en alusión a la importancia del personaje en cuestión, que sin embargo en la película no llega a tener nombre. 


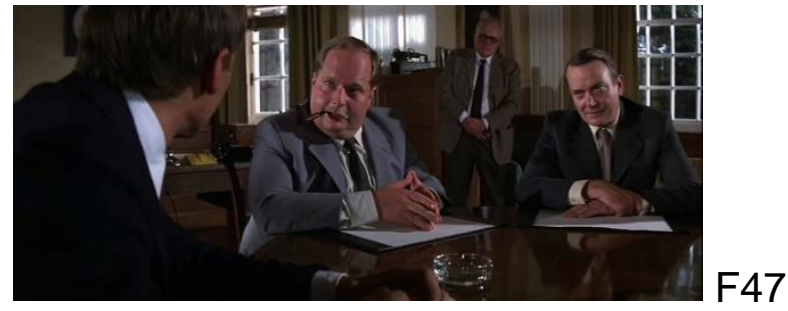

No se nos informa de ninguna reacción adicional por parte de Jones en esta reunión, pero cuando sale y es cuestionado por Marion, sus palabras son "They don't know what they've got there".

La película sí desvela quiénes son esos top men que se están encargando del Arca: operarios de un gigantesco almacén en el que el Arca es archivada dentro de una caja con las palabras "TOP SECRET" (F48), dando lugar al último plano del film (F49), sobre el que empiezan a aparecer los títulos de crédito finales, y que recuerda sobremanera al final de Citizen Kane (Welles 1941), solo que aquí quien acapara todos esos posibles tesoros no es un ciudadano particular, sino el ejército y por ende el gobierno de los Estados Unidos, aunque no sepan muy bien qué se traen entre manos.
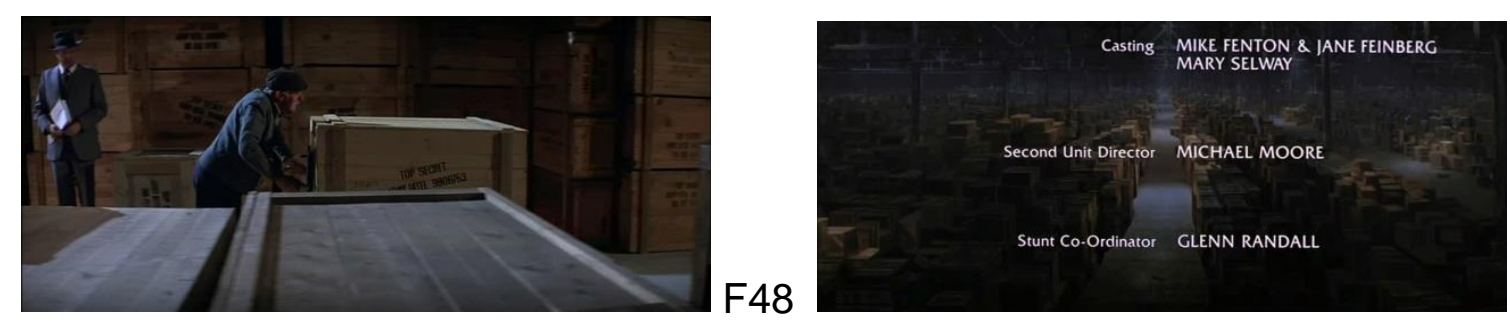

F49

Las relaciones de Indiana Jones con las mujeres, aparte de la fascinación que produce en sus alumnas, se cifran en la figura de Marion Ravenwood, hija del antiguo mentor del arqueólogo. Marion forma parte del pasado de Jones, ya que, según se va desvelando en el film, habían tenido una relación sentimental previamente. Quien la menciona por primera vez en la película es el propio Jones "Suppose she'll still be with him?"- en su conversación con Brody, antes de salir en busca del Arca. Este último remarca que "Marion's the least of your worries, believe me, Indy". Pero aunque constituya la menor de sus preocupaciones, no deja de ser una preocupación, y de hecho es por ella por quien comienza la búsqueda del Arca.

Localizamos visualmente a Marion en la taberna nepalí que regenta, ganando un concurso de bebedores frente a un robusto rival: decididamente esta chica no parece alguien a quien haya que cuidar, sino alguien de quien hay que tener 
cuidado. A lo largo de sus apariciones en el film, la joven alterna de manera algo incongruente entre esa imagen de chica dura y la de fémina asustada, pero la que más convence es la primera. Como hemos visto en el apartado dedicado a la acción, cuando ambos protagonistas se encuentran por primera vez en el texto fílmico, acaban saltando literalmente chispas, ya que el local termina siendo pasto de las llamas.

La llama, en realidad, la porta Marion tras su primer reencuentro con Indiana: metafóricamente, en forma del medallón que él busca, y literalmente, por la luz que la ilumina (F50). Parte de la película se dedicará a intentar colmar el deseo de la chica, aunque Jones parezca más dedicado a otros asuntos. Ella es quien toma la iniciativa de mantener la relación comercial que se establece entre ambos, gracias al medallón (F51). "I'm your goddam partner!", le dice ella.
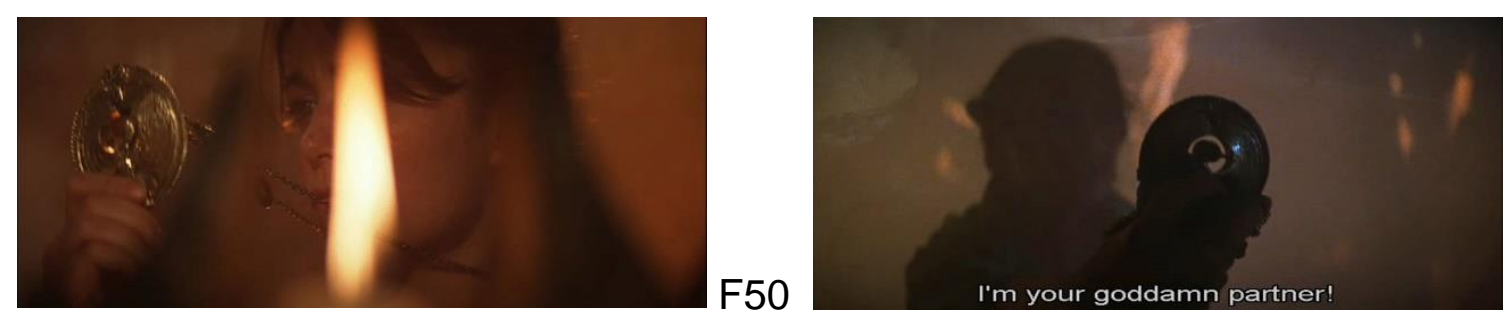

F51

La relación que se desarrolla entre ambos pasa por diversos altibajos que producen algún momento de comicidad, como cuando Indiana localiza a Marion en una tienda del campamento a las afueras de El Cairo, tras haberla dado por muerta. En lugar de liberarla, prefiere que permanezca prisionera, para no ser descubiertos mientras encuentran el Arca, lo que provoca la lógica indignación de la chica (F52).

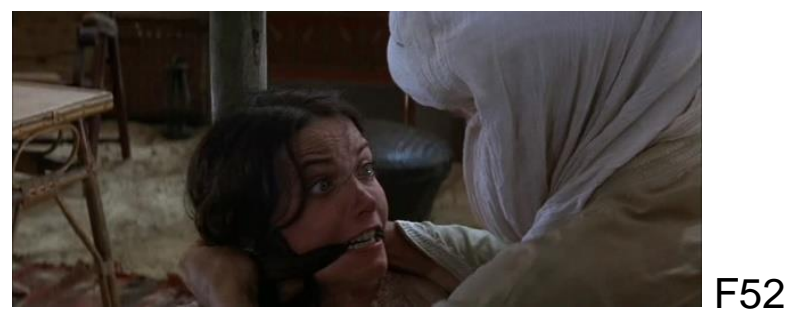

De hecho, Belloq la trata más como una dama que el propio Jones, como hemos señalado en otra publicación: 
Indiana's relation to Marion is shadowed by the one she has with Indiana's double, Belloq (Paul Freeman), who does behave like a Don Juan, a feature which is so characteristic of James Bond and which Indiana Jones is incapable of displaying in any of the films. (Díaz-Cuesta 1998: 222)

Es Belloq quien le ofrece la oportunidad a Marion de ponerse un vestido blanco que realza su feminidad en la tienda del campamento de El Cairo (F53), jugando ligeramente con el mito de Cenicienta, algo que también sucede en otra película posterior del director, Always (Spielberg 1989b), cuando Dorinda (Holly Hunter) se ciñe otro vestido blanco que deja boquiabiertos a los bomberos aéreos.

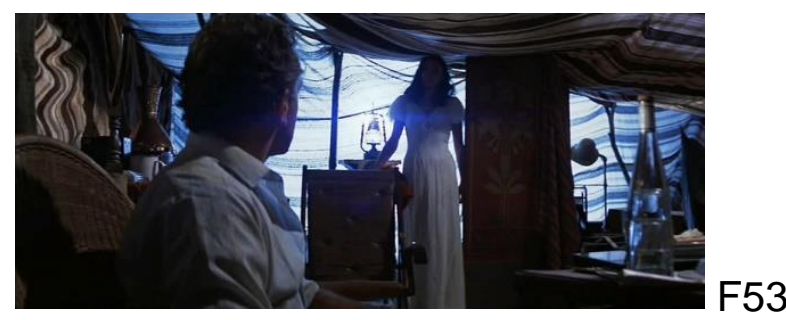

En ambas ocasiones el revestimiento tradicionalmente femenino del vestido contrasta con otras situaciones en las que ambos personajes se muestran en actitudes más tradicionalmente masculinas. En el caso de Marion, se verá obligada a llevar puesto ese vestido hasta que llega al barco de Katanga. Cuando ella se vuelve a encontrar a Indiana, primero lo rechaza, pero al ver que están rodeados de serpientes literalmente se sube encima de él (F54), en una nueva vis cómica que juega con el estereotipo de la mujer sintiéndose protegida por el hombre.

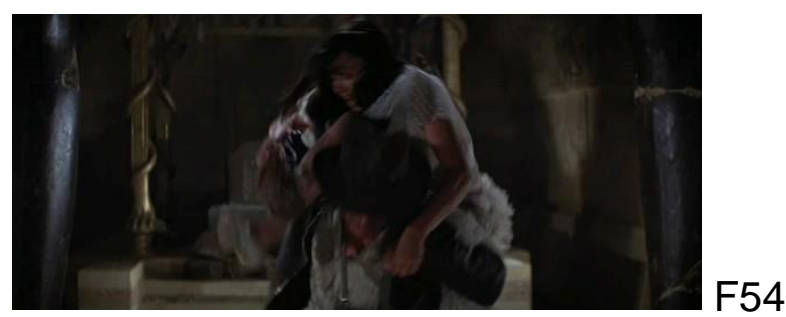

De todo el texto fílmico hay una escena que sobresale sobre las demás en cuanto a la relación entre Marion e Indiana: la que transcurre en el camarote del barco capitaneado por Katanga. Marion encuentra placer en su imagen reflejada en 
el espejo del camarote, vistiendo un camisón que le ha cedido el capitán (F55), mientras Indiana se concentra en el dolor acumulado de sus diversas heridas y magulladuras. Aunque por un momento el arqueólogo es capaz de verse a sí mismo como una figura aislada en el espejo, tras el golpe que le propina la chica con el propio espejo, ambos comparten imagen en el mismo (F56), en un trasunto de fase del espejo lacaniana.
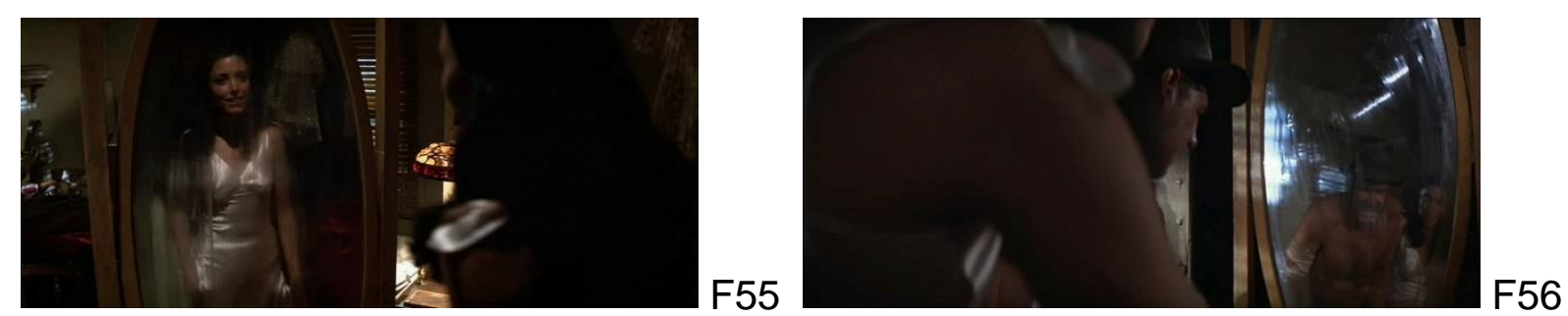

Marion le dice, literalmente, "You're not the man I knew ten years ago", y aunque él responde "It's not the years, honey, it's the milage", y "I don't need a nurse", frente al movimiento de ella que le hace a él adoptar una postura más cercana a la fetal (F57), Marion lo llama bebé: "You're such a baby...".

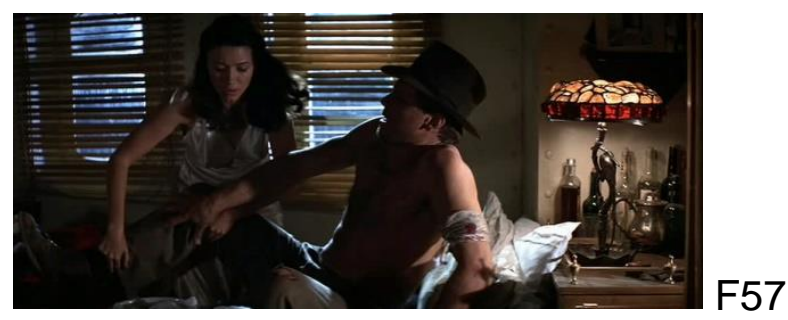

Tras este intercambio de palabras se sucede una serie de besos que la chica le da a Indiana en diferentes partes de su cuerpo, besos que comienzan siendo castos, propios de una madre hacia un hijo que está herido, en el codo y sobre todo en la frente (F58), hasta culminar en el que le da en los labios (F59), que concluye con el arqueólogo dormido, en una nueva referencia al mundo de los cuentos de hadas, en una suerte de bello durmiente del revés que cae en sueños al ser besado. Se juega con la referencia, trastocando las expectativas de la chica y de la audiencia. 

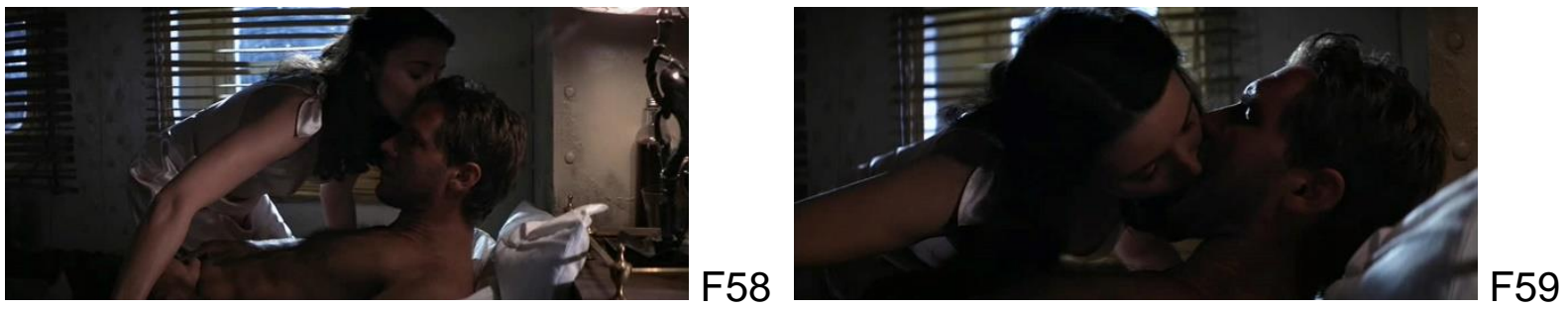

Marion comparte con Jones el momento de la apertura del Arca, que comentamos en el siguiente apartado, y cuando esta última se vuelve a cerrar ambos se cogen de las manos, con el Arca, símbolo de Dios, iluminada (F60), como si su unión estuviera bendecida desde las alturas. Se trata de un plano primordialmente a contraluz, tan típico de Spielberg, en el que además de los elementos que acabamos de mencionar sobresale la verticalidad del poste al que han estado atados, que rima con el obelisco ya mencionado que aparece dos planos después.
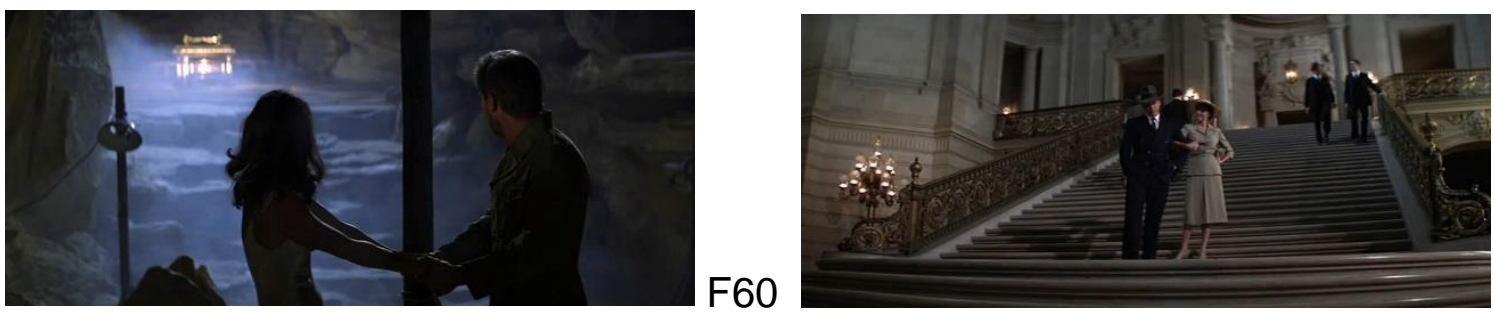

F61

La chica goza además del honor de aparecer junto a Indiana Jones en la última imagen del mismo en el film, cogidos del brazo en actitud matrimonial (F61), como si se acabaran de casar y la escalinata fuera la de una iglesia o un juzgado. A pesar de ello, el matrimonio queda como una de las instituciones pendientes del Dr. Jones.

\section{El mundo interno en Raiders of the Lost Ark}

A menudo se considera a Indiana Jones únicamente como un aventurero ávido de vivir experiencias extraordinarias. Los propios creadores de la idea inicial, Lucas y Spielberg, acordaron en su reunión matriz que el arqueólogo "would be an old-fashioned hero, faithful only to his own quirky code of honour" (Baxter 1996: 3). Pero no debemos olvidar que el trasfondo de sus aventuras conserva una alta carga de sentido religioso ${ }^{3}$, aunque el héroe las rechace como "superstitious hoccus

\footnotetext{
${ }^{3}$ Para una exploración a fondo sobre las connotaciones religiosas y mitológicas de Raiders, véase Tomasulo (1982).
} 
pocus" poniendo en valor su pistola cuando el Dr. Brody le da el visto bueno para salir en busca del Arca.

La primera pista que nos conduce hacia esa interioridad que Jones pretende ocultar aparece en la primera entrevista con los representantes de la Army Intelligence. Justo antes, al disponerse a salir del aula, el profesor coge bajo el brazo, en primer lugar, un libro de enormes dimensiones que instantes después descubrimos es una Biblia (F62).

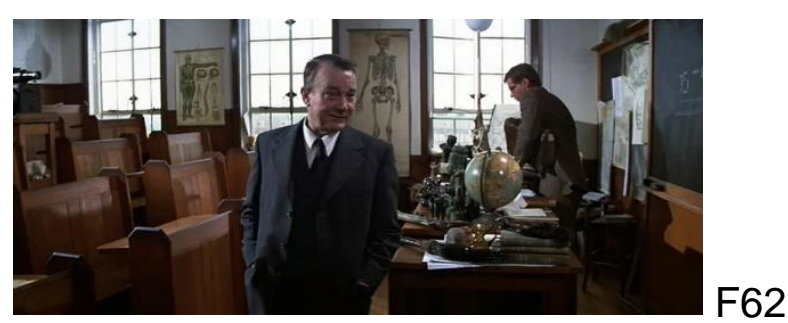

En el auditorio en el que se reúne con los representantes, cuyas vidrieras y estrado recuerdan a una iglesia, lo último de lo que se desprende es también esa Biblia que le será tan útil para ilustrar la explicación detallada que da, junto con el Dr. Brody, sobre qué es y qué supone el Arca de la Alianza. Ante la ignorancia y el aparente descreimiento de los representantes, Jones les dice "Did you guys ever go to Sunday school?", como dando a entender que él sí asistió a sesiones de catecismo. Además, cuando busca la imagen del Arca que hay en su Biblia, da la impresión de que localiza esa página sin tan siquiera buscarla, como si fuera algo que tuviera muy mirado y señalado. Ante el detalle de la ilustración, inquirido por uno de los representantes, Jones le dice que lo que ahí se muestra es "Lightning. Fire. The power of God or something", indicando esa falta de fe de la que alardea poco después en su casa, pero que resulta poco convincente cuando sus enemigos se disponen a abrir el Arca en el clímax del film.

La apertura del Arca trae como consecuencia inmediata diversas explosiones en los aparatos eléctricos que están siendo usados principalmente para iluminar el emplazamiento, de manera similar a lo que sucede en Close Encounters of the Third Kind (Spielberg 1977) cuando los extraterrestres se manifiestan. Aquí esas explosiones resultan inconsistentes, ya que no afectan a todos los aparatos, y quedan algunos reflectores en funcionamiento: hacía falta que hubiera algo de luz para iluminar la escena hasta que la propia arca emanara luz. La decisión de Jones de no mirar no está justificada explícitamente en el texto, y puede ser achacable a una lectura previa del arqueólogo en la que se advirtiera de los peligros de mirar hacia esa luz divina. El hecho de que sólo Jones y Marion sobrevivan a la cólera divina, con el añadido de que se les corta la cuerda con la que estaban atados, 
corrobora la fe escondida del héroe. Lo que le ha sucedido al resto de la comitiva estaba claramente anunciado por la ilustración de la Biblia que se había mostrado en detalle al principio (F63), pero nada daba a entender que quien no mirara se salvaría.

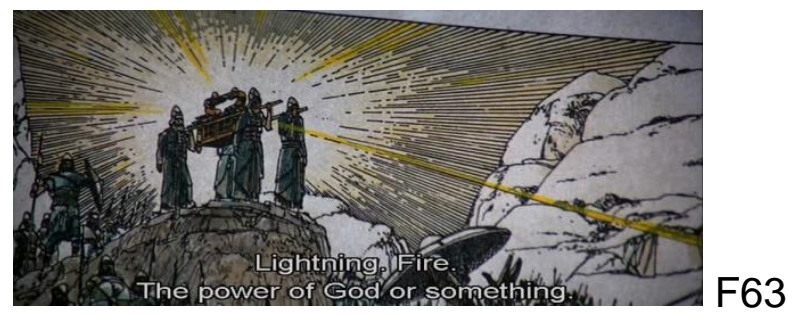

Jones no puede ocultar otro rasgo de su interioridad: su aversión a las serpientes, tema que es introducido de manera jocosa en la escena del hidroavión con la que concluye la secuencia dedicada al ídolo dorado. Visualizamos esa primera serpiente del film sobre la entrepierna del héroe (F64), en un plano subjetivo que hace que compartamos el punto de vista del arqueólogo. Resulta paradójico que las serpientes constituyan el talón de Aquiles de Jones, habida cuenta de que su arma favorita es el látigo, con apariencia y movimientos propios de esos reptiles: el héroe puede dar vida a su arma, pero afronta serias dificultades cuando se aproxima a un ofidio. Por ello resulta aún más valerosa su hazaña en el Pozo de las Ánimas, repleto de áspides, yendo a caer enfrente de una cobra (F65).
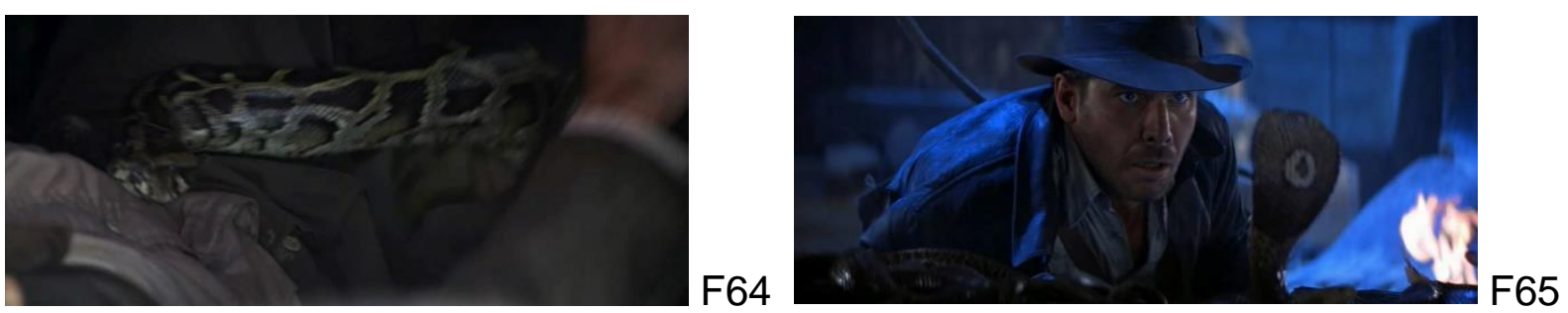

"Why did it have to be snakes?", podemos preguntarnos, al igual que Jones. Aparte de la explicación diegética que se da en otra entrega de la saga para la repulsión que le provocan al arqueólogo, la serpiente goza de una reconocida presencia bíblica en el libro del Génesis. Aunque las razones por las que la serpiente representa al mal tienen que ver con la religión cananea, muy popular en la época en la que se escribió este libro, según recoge Ariel Álvarez Valdés (1999), la tradición ha asociado a este animal con el Diablo. El aparentemente descreído Jones sufre aversión hacia la representación bíblica del mal. 


\section{Conclusiones}

Aunque este texto fílmico no incorpore en su título el nombre de Indiana Jones, su figura se ha hecho tan reconocible que esas dos palabras constituyen el comienzo de los títulos de las dos películas de la saga que se han realizado con posterioridad por el momento. Esa figura se funde y se confunde con la de su intérprete, Harrison Ford, fruto de un ejercicio de cásting que se ha demostrado completamente afortunado.

Steven Spielberg propone en esta película un prototipo de hombre cuyo cuerpo, ataviado de diversas maneras, responde de maneras diferentes a los estímulos dependiendo de la indumentaria y sobre todo de la ocasión. Se trata de un cuerpo de importante atracción física con el que los espectadores masculinos pueden fácilmente sentirse identificados.

El personaje que representa Harrison Ford recurre a todo tipo de argucias para evitar las confrontaciones físicas, de las que acaba saliendo bastante malparado, aunque con mejor fortuna que sus adversarios, que suelen perecer como consecuencia de las acciones de Jones y/o de la ayuda de algún aliado. A diferencia de lo que sucede en Duel, este protagonista sí es capaz de conducir un camión con habilidad.

Las habilidades de Jones sufren altibajos en su paso por las aulas universitarias, ya que se desenvuelve mejor ataviado de arqueólogo explorador que de arqueólogo académico. La combinación de ambas facetas le hace merecedor del interés del gobierno estadounidense, representado por la Army Intelligence, que le visita y finalmente se hace cargo de su hallazgo.

El mundo externo se ve completado por la figura de Marion Ravenwood, presentada como una mujer capaz de enfrentarse a los hombres en terrenos tradicionalmente reservados para ellos, pero capaz también de acoger en su regazo maternal al héroe cuando se acerca el final de la aventura. La penúltima toma del film deja una impronta matrimonial en la pareja, aunque de momento no se puede hablar de un señor y una señora Jones.

Parece como si la experiencia de estar presentes en la apertura del Arca les hubiera marcado a ambos. En ese momento se vislumbra que Jones puede tener más fe en Dios que la que manifiesta explícitamente, hecho que se vería corroborado por su talón de Aquiles, las serpientes, tradicionalmente asociadas al Maligno.

Esa interioridad permanece oculta durante la mayor parte del tiempo, de la misma manera que no se muestran en pantalla las imágenes más difíciles de soportar. En la tensión clásico/postclásico, Spielberg opta principalmente por la primera opción, evitando que el espectador sufra en demasía por lo que ve, acción 
que le es reservada al héroe, con la excepción precisamente de la apertura del Arca. Durante la mayor parte del film el espectador puede buscar y encontrar esa silueta que, desde el estreno de esta película, no ha dejado de ser reconocible, aún más, quizá, para el gran público, que la última imagen de John Wayne (Ethan) en The Searchers (Ford 1956). Más allá de la imagen se sitúa el mito (Zunzunegui 1981: 70).

\section{Referencias}

Álvarez Valdés, Ariel. 1999. "Quién era la serpiente del paraíso?”. Revista Didascalia 523. Disponible en http://www.mercaba.org/FICHAS/Didascalia/Oquien era la serpiente del par aiso.htm. Consultado el 18 de enero de 2005.

Baxter, John. 1996. Steven Spielberg: The Unathorized Biography. Londres: HarperCollins.

Caldevilla Domínguez, David. 2005. El sello Spielberg. Madrid: Editorial Vision Net.

Chatman, Seymour. 1986 (1978). Story and Discourse: Narrative Structure in Fiction and Film. Ithaca y Londres: Cornell University Press.

Connell, Raewyn. 1995. Masculinities. Cambridge: Polity Press.

Coppola, Francis Ford (dir.). 1974. The Conversation. EEUU: Directors Company, Coppola Company, American Zoetrope, Paramount Pictures.

Coppola, Francis Ford (dir.). 1979. Apocalypse Now. EEUU: Zoetrope Pictures.

Díaz-Cuesta, José. 1998. "Searching for Traces of Myth in the Indiana Jones Saga". En Blesa, Túa (ed.). Mitos vol. II. Zaragoza: Asociación Española de Semiótica y Tropelías. 220-224.

Ford, John (dir.). 1956. The Searchers. EEUU: C. V. Whitney Pictures y Warner Bros. Pictures.

Hopper, Jerry (dir.). 1954. Secret of the Incas. EEUU: Paramount Pictures.

Kirkham, Pat, y Thumim, Janet (eds.). 1993. You Tarzan: Masculinities, Movies and Men. Londres: Lawrence and Wishart.

Loshitzky, Yosefa (ed.). 1997. Spielberg's Holocaust: Critical Perspectives on Schindler's List. Bloomington: Indiana University Press.

Lucas, George (dir.). 1977. Star Wars. EEUU: Lucasfilm y Twentieth-Century Fox Film Corporation.

Lucas, George (dir.). 1980. The Empire Strikes Back. EEUU: Lucasfilm. 
Rissik, Andrew. 1984. "Steven Spielberg: Indiana Jones and the 007 myth". Films and Filming 363, 13.

Sánchez-Escalonilla, Antonio. 1995. Steven Spielberg. Barcelona: Royal Books.

Sánchez-Escalonilla, Antonio. 2005. Steven Spielberg: Entre Ulises y Peter Pan. Madrid: Cie Dossat 2000.

Scott, Ridley (dir.). 1982. Blade Runner. EEUU, Hong Kong y Reino Unido: Ladd Company, Shaw Brothers y Warner Bros.

Silet, Charles L. P. (ed.). 2002. The Films of Steven Spielberg: Critical Essays. Lanham, Maryland y Oxford: Scarecrow Press.

Spielberg, Steven (dir.). 1972. Duel. EEUU: Universal TV. [Estrenada previamente el 13 de noviembre de 1971 en una versión más breve para televisión].

Spielberg, Steven (dir.). 1975. Jaws. EEUU: Universal Pictures para Zanuck/Brown Productions.

Spielberg, Steven (dir.). 1977. Close Encounters of the Third Kind. EEUU y Reino Unido: Columbia Pictures Corporation en asocación con EMI Films.

Spielberg, Steven (dir.). 1981a. Raiders of the Lost Ark. EEUU: Lucasfilm y Paramount Pictures.

Spielberg, Steven. 1981b. "Of Narrow Misses and Close Calls". American Cinematographer 52/11, 1100-1102, 1138-1142, 1160-1168.

Spielberg, Steven (dir.). 1984. Indiana Jones and the Temple of Doom. EEUU: Lucasfilm y Paramount Pictures.

Spielberg, Steven (dir.). 1989a. Indiana Jones and the Last Crusade. EEUU: Lucasfilm y Paramount Pictures.

Spielberg, Steven (dir.). 1989b. Always. EEUU: Amblin Entertainment, United Artists, Universal Pictures y U-Drive Productions.

Spielberg, Steven (dir.). 1993. Schindler's List. EEUU: Amblin Entertainment y Universal Pictures.

Tomasulo, Frank P. 1982. "Mr. Jones Goes to Washington: Myth and Religion in Raiders of the Lost Ark". Quarterly Review of Film Studies 7/4. 331-340.

Welles, Orson (dir.). 1941. Citizen Kane. EEUU: RKO Radio Pictures y Mercury Productions.

Zunzunegui, Santos. 1981. "La banalidad como sistema”. Contracampo 25/26, 6770. 